\title{
Article \\ Queerly Unequal: LGBT+ Students and Mentoring in Higher Education
}

\author{
Brooke Erin Graham \\ Department of Sociology and Anthropology, North Carolina State University, Raleigh, NC 27607, USA; \\ begraham@ncsu.edu
}

Received: 13 May 2019; Accepted: 29 May 2019; Published: 5 June 2019

\begin{abstract}
Sociological research has illuminated the importance of mentoring relationships, especially in regard to education. The literature has also shown that mentoring can help disadvantaged students access social and cultural capital that aids their academic achievement. Furthermore, mentoring relationships are more successful between mentees and mentors of the same race, class, or gender. However, there is little research about queer students' experiences with mentoring relationships in regard to education. In an effort to expand the literature on mentoring relationships and queer students I conducted ten in-depth interviews with queer identified undergraduate students at a large university in the Southeast United States. Using these interviews, I examined respondents' perception of their social exclusion, coping through resiliency, and prosocial behavior through mentoring others. I found that being openly queer posed an identity-based risk for students' ability to access mentoring relationships, in turn this risk increased their perception of resiliency and prosocial behavior.
\end{abstract}

Keywords: queer students; mentoring; risk; resiliency; prosocial behavior

\section{Introduction}

Sociological research has examined mentoring relationships in almost all social institutions: work, religion, education, family, and more. Sociological research has illuminated the importance of mentoring relationships, especially in regard to education. The literature has also shown that mentoring can help disadvantaged students access social and cultural capital that aids their academic achievement. Furthermore, mentoring relationships are more successful between mentees and mentors of the same race, class, or gender. Students with marginalized identities are less likely to have a mentoring relationship, further reinforcing the systematic inequality in social relations for students with marginalized identities; however, there is little research about queer students' experiences with mentoring relationships in regard to education. In an effort to expand the literature on mentoring relationships and queer students I conducted ten in-depth interviews with queer identified undergraduate students at a large university in the Southeast United States. Using these interviews, I examined respondents' perception of their social exclusion, coping through resiliency, and prosocial behavior through mentoring others.

\section{Literature Review}

\subsection{Mentoring and Education}

Anderson and Shannon (1988) define mentoring as

a nurturing process in which a more skilled or more experienced person, serving as a role model, teaches, sponsors, encourages, counsels and befriends a less skilled or less experienced person for the purpose of promoting the latter's professional and/or personal development. 
Mentoring functions are carried out within the context of an ongoing, caring relationship between the mentor and protégé. (p. 40)

Other definitions of mentorship emphasize sharing wisdom, encouraging development through guidance or instruction, and building a trusting relationship (DuBois and Silverthorn 2005).

Mentorship is a resource utilized by various students, although not always intentionally, in order to further their academic career. "Very important nonparental adults" have strong mentoring influences on youths' ability to access higher education (Beam et al. 2002). Nonparental adult mentor relationships are also correlated with higher academic scores and healthier social ties with family, friends, and classmates (Beam et al. 2002; DuBois and Silverthorn 2005; Farruggia et al. 2013). Adult mentors are able to combine fun and maturity, supporting the mentees autonomy and independence while role modeling (Allen and Land 1999; Beam et al. 2002; Rhodes 2002; Rhodes 2005). Not all mentorships are created equally - the level of closeness between mentor and mentee tends to correlate to the success of the relationship for the mentee (Liao and Sánchez 2016; Ortiz-Walters and Gilson 2005; Santos and Reigadas 2005; Schueths and Carranza 2012). Students with mentors do better in school overall (DuBois and Silverthorn 2005). Mentoring relationships are often an important resource for students, particularly in regard to education. The benefits of mentoring relationships are numerous, with mentors often providing professional, personal, and/or emotional resources (Anderson and Shannon 1988). Bourdieu's (1994) theoretical framework of cultural and social capital are instrumental when understanding the impacts of mentoring relationships within education. Cultural capital refers to a symbolic knowledge and prestige that comes with higher levels of education and status, and social capital refers to one's connections, networks, and accessibility to cultural capital. Mentors are able to transmit social and cultural capital to mentees in order to aid their navigation of higher education; although the socialization of social and cultural capital begins with families, it is greatly influenced by peers, social networks, and values (Lareau 2003; Malacarne 2017; Mullen 2010; Staples 2014). Some students seek out multiple mentoring relationships, as having a variety of networks allows students to have various needs met by a multitude of individuals, furthering their overall social capital gain (Beam et al. 2002; Chase 2010).

\subsection{Mentoring Benefits for At-Risk Students in Education}

Students from families that do not possess 'standard' social and cultural capital, mentorship proves even more effective in obtaining higher educational outcomes than for middle class students (Erickson et al. 2009). Students that come from low-income families or belong to a minority racial or ethnic group tend to rely more on mentorships to attain access to and navigate institutions of higher education than other more privileged students must (Duntley-Matos 2014). Mentors often serve as a link to the system of education for at-risk students, aiding students in navigating the unfamiliar terrain of higher education (Hinsdale 2011; Staples 2014). Mentors from an academic background are more successful than other mentoring relationships, especially for students of color and low-income students that do not have access to college educated/experienced mentors within their own family (Chang et al. 2010; DuBois and Silverthorn 2005; Fruiht 2015; Fruiht and Wray-Lake 2013; Stanton-Salazar 2011). Mentoring relationships can evolve out of students' communities, thus often pairing the student with a mentor of a similar sphere of social and cultural capital, gained through early childhood socialization (Parcel and Hendrix 2014).

Mentorship aids students' ability to access higher education; however, this privileges already advantaged students because of their social networks and mentoring resources, allowing them easier access to mentoring relationships (Erickson et al. 2009). One of the most frequently studied marginalized populations within education-working class students-has a unique set of cultural and social capital that tends to leave them disadvantaged within the institution of education (Lareau 1987, 2003; Stanton-Salazar and Spina 2003). The system of education is founded on middle and upper class cultural capital, and the behaviors, values, and norms of upper class cultural capital are rewarded within schools. Teachers tend to have higher expectations resulting in differential treatment for students from 
middle class backgrounds than low-income students, even from optical judgments alone (Rist 1970). The social capital that is expected of students in the institution of education requires traits of middle or upper-class childhood socialization, causing working class and poor students to find barriers within behavior, communication, and relationship-building (Jack 2016; Stanton-Salazar 2011). Additionally, the social capital and social networks relied on for educational and professional connections serve to reproduce race and class inequalities (Royster 2003).

Racial identity is critical in mentor-mentee relationship success (Thomas 2005; Hurd and Sellers 2013; Noy and Ray 2012; Ortiz-Walters and Gilson 2005). Structured mentoring relationships are often built into programs at universities, especially for disadvantaged racial/ethnic groups. These types of assigned mentorships that are formal (Erickson et al. 2009), as opposed to naturally occurring mentorships (Gaddis 2012). Students of color, first-generation students, and female students are less likely to have successful professional mentorships within both undergraduate and graduate school (Katz and Hartnett 1976, p. 8; Noy and Ray 2012; Reskin 1979). Intersecting oppressions, such as being a person of color and a woman, create less supportive advising situations than privileged students (Noy and Ray 2012; Strayhorn and Saddler 2008). Forms of dissatisfaction and exclusion in mentorship often occur along racial lines; students of color report advisors being less respectful of their ideas than white students, and the marginalization of the contributions of scholars of color are supported by this research (Morris 2017; Padilla and Chávez 1995; Turner and Myers 2000). Black and Latinx students have a shortage of mentors of similar backgrounds due to systematic exclusion from these institutions (Ortiz-Walters and Gilson 2005; Santos and Reigadas 2005; Schueths and Carranza 2012). The importance of racial and ethnic similarity and shared experiences between the mentor and mentee is supported by the aforementioned studies, although there is a structurally caused shortage of mentors of various disadvantaged backgrounds. In order to adapt to fit the mold of the institution, many students, of various disadvantaged identities, must transform their identities, behaviors, and language to the expected standard, often by choice or force, in order to succeed (Lehmann 2017).

Research examining the relationship between at-risk youth and long term outcomes has taken strides to conceptualize the relationship between support and resiliency. Just as social connections such as mentoring relationships can be pivotal to the academic success of adolescents and young adults, resiliency to cope with life struggles has previously been attributed to the connections one maintains with family and community members (DuBois and Silverthorn 2005; Ungar 2004). Posited throughout the literature is the claim that maintaining strong ties to parents and community members is the primary factor in determining resiliency of adolescents and young adults (Werner et al. 1971; Ungar 2004). That is, previous literature posits that having strong supportive connections (like a mentoring relationship) increases the resiliency of individuals (Ungar 2004). Queer students' embodiment of their queer identity poses an identity-based risk for students, similar to how having a deficit of material resources poses a 'risk' (Werner et al. 1971). This identity-based risk could potentially alter queer students' experiences with social support and resilience. Current research has illuminated the differences in material resources, and this research posits that identity-based risk, opposed to solely resourced-based understandings of risk, alters the process of resiliency as presented in the current body of literature.

\subsection{The Queer Community}

The queer community encompasses a variety of individuals that do not comply with the heteronormative standards of mainstream society, due to gender and/or sexuality identities that are neither respected nor normalized by the current forces legitimating the social order in larger society. The embodiment of one's identity as a member of the queer community alters the lived experiences of queer students, and only through understanding the perception of queer students' lived experiences can we attempt to understand the ways through which marginalized identities alter the processes of mentorship (Collins 1991, 2005). Queer students, like other structurally disadvantaged groups, often employ coping strategies to 'fit' the institution of higher education (Chica 2019). 
Mentoring commonly occurs between members of minority communities (Mulcahy et al. 2016). Just as with other identities examined in the literature on mentorship, LGBT youth benefit from mentoring relationships, and mentorships between a LGBT mentor and LGBT mentee are the most successful (Bird et al. 2011; Russell and Horne 2009). When a queer student attempts to forge a mentoring relationship without knowledge of the mentor's identity, they often "test the waters" though mentioning LGBT political issues in order to read the potential for success within the relationship, an act of emotional labor the queer folks must often utilize in their daily lives (Mulcahy et al. 2016). Current research illuminates the understanding that having a mentor of a similar background to the student increases the student's views of the relationship and relationship success (Hurd and Sellers 2013; Noy and Ray 2012). Identity similarities between mentors and mentees can aid the development and utility of the mentoring relationship; however, there is a shortage of queer mentors within education. Russell and Horne (2009) detail an important aspect often neglected by research: the importance of allies for mentorship, due to the small size of the openly queer community (Moore 2015), it is important for students/mentees to locate mentors that are queer-positive, even if they do not personally identify within the community. Involvement within the queer community is beneficial to all students, regardless of their personal identification (Nicol 2011), thus supporting the inclusion of allies into safe spaces and queer positive conversations within higher education. The development of increased social knowledge on issues of structurally disadvantaged communities would aid in increasing mentorship and changes within the structure of higher education itself to better incorporate the needs of queer students (Blonshine 2014; Duntley-Matos 2014).

Just as social connections can be pivotal to the academic success of adolescents and young adults, both resiliency and prosocial behavior have previously been attributed to maintaining strong social connections with family and community members (DuBois and Silverthorn 2005; Staub 2004, 2005; Ungar 2004; Werner et al. 1971). This research posits that queer students' embodiment of their queer identity poses an identity-based risk for students-similar to how having a deficit of material resources poses a 'risk' for students resiliency (Werner et al. 1971; Ungar 2004). This identity-based risk alters queer students' experiences with social support and resilience. Having social support through parents, peers, and role models have been shown to predict prosocial behavior, behavior that aids others in society (Batson 1991; Dodge et al. 1990; Piliavin and Callero 1991). However, this study identifies the process through which exclusion and isolation due to queer identity serve to motivate individuals to enact prosocial behavior through mentoring others. Other scholars have noted how suffering or adverse life experiences can also enhance individuals' motivation to help others, most notably out-groups within society (Staub 2003; Vollhardt 2009). This study contributes to the literature recognizing adverse life experiences can, in some cases, serve as motivation for prosocial behavior. Currently the literature has not detailed the process through which queer students cope with the lack of social support they receive in high school, which this study proposes occur through a desire to live authentically and seek institutional supports, while peer mentoring other queer students.

\section{Results}

\subsection{Barriers to Social Support: School}

High school is a challenging time in an individual's development, but for queer students, high school often comes accompanied with discrimination not faced by their heteronormative peers. During interviews respondents often reflected on their own coming out experience, a moment many respondents identified as a turning point, an act of seeking authenticity and independence. After coming out respondents discussed not having the same levels of social support or mentorship that their heteronormative peers were able to access. Similarly to the sentiments expressed by fellow respondents Anita, a bisexual Black woman, said she "had a tough time in high school, not just personally, academically at times." Anita was not alone, though. Anne (they/them) recounts the experience of high school as a lonely period of time in their life: 
"High school was kind of like a lonely time and I didn't confide much in my parents because I was going through some mental health stuff. Um I didn't want them to worry about it, or know about it, you know. I guess I had a couple of teachers I talked to but not in any kind of like detail, more just like general. Uh, I uh, I mean I had a support system through my friends, um, somewhat. All of my friends, well most of my friends, were um straight and Catholic, so that was um, that was that was, it was difficult to talk about a lot of the things that were bothering me with them because they just either didn't care or didn't get it, um so, high school was fairly lonely."

Feeling isolated from others due to their queer identity, many queer students are unable to access social support that comes much more easily to their heteronormative peers.

Interestingly Ezera, a Latina bisexual cis-woman, did not go to college directly out of high school, although she, unlike almost all other participants, did have a mentor. She recounted:

"It was stuff I had, I had to figure out for myself. Even though I had the resources in high school to like, I could have gone straight to a four year university after I graduated but like I ... I think the issue was, I didn't know what school I wanted to go to. so, and I felt like at the time that financially it probably wasn't a good idea to go to a four year university. I could've tried to go for like scholarships but like that felt, it just felt like a lot of work and a lot of pressure, and I just didn't feel comfortable. So I ended up going and applying and doing testing for [local school] Tech. instead. It was just a different journey, and I ended up saving money along the way because of it ... I mean I was pretty much able to navigate things on my own for the most part. I mean I had assistance with friends just in like finding resources and spaces. But like most part it was me. I was at my most confident that I could. It wasn't that I lacked or needed a mentor, it was that I was at the point where I could mentor myself ... I think one of the best parts about our community is that it is a lot of self-discovery. And it requires a lot of focusing on trying to figure out what you need on your own. And yes, we do need friends and allies and any other way we can like help look more into our identity. But it really is a personal journey."

Interestingly Ezera recounted a mentor in high school, and did not attend college directly out of high school; whereas, other respondents without a mentor did attend college directly after high school. In this situation the mentoring relationship aided Ezera's sense of comfort and safety, encouraging the transition to community college before leaving for a four year institution. Even when Ezera left for college she considered proximity to family:

"I was going to community college when I was, when it was, deciding to go to a four year university, and I just graduated with my associates in arts and I was like "alright I need to send out some applications to different schools" so I decided I'll pick schools that I can get to easily. That are within driving distance so I don't have to worry about being too far from home if I ever need to go back home."

Similarly to Eli, Ezera felt that she was able to mentor herself, as she went on to detail the process of seeking authenticity and self-discovery, aiding in the resiliency of finding out "what you need on your own."

\subsection{Barriers to Social Support: Home}

Social support was lacking not only in school, but also in their homes. A participant with a fellow queer sibling, Mars, who is nonbinary, perceived their social support was higher than queer students in heteronormative family structures. However, Mars was out to all the facets of their life except for their parents. Coming from an upper-middle class family with a nonbinary sibling they still felt overall comfortable, yet not ready to come out to their parents quite yet. Mars said, 
"They've [their parents] been really nice with Jamie, my younger sibling. The new name has been difficult and the pronouns are definitely a struggle and both of my parents were raised by English teachers so it's like "they is plural" and I'm like who cares? But I don't say that because it's my parents. My parents were having a really difficult time with my younger sibling's new name and I went out to breakfast with my mom I guess this summer and she was talking to me about it, and she was like "it's such a challenging thing." And I think one reason I haven't came out is because my parents confide in me all the struggles of like having a kid that is a nonbinary assigned female kid that likes women and came to terms with all of that at like age 12. So they've been out forever, and recently decided they'd like to go by "Jamie" but my parents took it really personally because both of our names have a lot of meaning and blah blah blah. And I was like "you have the choice and it's like you don't get to pick the way you love people." You can't love Jamie the way you've loved anyone else. You've got to love them for them, and then when I mentioned that Jamie was like thinking about moving out and not coming back it was like- oh wow this is a real thing I'm doing that's harm."

Even though Mars claims they feel support and they felt that they could speak about queer issues with their parents, they were not yet able to reveal that identity. In this way, even folks perceiving more support than their queer peers face discrimination and barriers to social support. I asked Anita, a bisexual Black woman, who comes from a low-income background, how her relationship with her family was, to which she replied,

"we just don't talk about it [her sexuality]. It's a weird thing, but nobody brings it up aside from my sister, but she's queer too, I think she's like exploring. She's a freshman now in college; she goes to [state school]. So I'm sure she'll start exploring that part. I wouldn't say I'm that close with my immediate family; I mean I brought it up a long time ago, we talked about it then, so there's no need to talk about it again. But that's my apprehension to what I've had my mom say honestly. She's the one who's had me turned off to talking about it."

Anita did not feel she could even discuss her sexuality with her family in any way, because attempts were quickly shut down by her mother. This barrier to social support limited Anita's ability to connect with her family, as they did not accept her sexuality.

\subsection{Lack of Mentoring Relationships}

The majority of the queer students interviewed were not able to identify a mentor in their life before entering college; many respondents felt this was due to their social isolation in high school. When asked about their experiences between late high school and early college, most of the students interviewed expressed the feeling of isolation during the transition from high school to college, as epitomized by Anne above. Many students perceived that they overcame this deficiency in support and aid through their self-reliance, independence, and resiliency. One respondent, Eli, expressed that they believe they were able to harness resiliency to cope in a healthy way. Eli, who identifies as gender fluid as well as pansexual and demisexual, stated,

"I didn't have anyone. I just kinda threw everything I had into school and ignored the rest of my life, so I didn't realize I needed anything like that [a mentor] until I got here, then I was like 'wow other people have like people to look up to, and have representation' but it was just me. I don't need anyone to look up to. Like I'll mentor myself, because I'm wonderful. No, I look up to myself because I worked my ass off to get here and to like keep myself afloat."

Eli came from a low-income background, and they feel the salience of their status as a queer individual has more greatly influenced their experiences both before and during their time at the university than their social class. Here Eli, like many other respondents in this project, expressed that their identity as a member of the queer community aided in their sense of resiliency, even while living with 
the risk of economic insecurity. Respondents who identified, and were out, as gender fluid, gender nonconforming, gender creative, or nonbinary were not able to identify a mentor in their lives before college, unlike two of the cisgendered respondents who were able to identify a mentor. The privilege of appearing heteronormative, or "passing," could also assert an influence on this disparity between identities and mentorship within the queer community. According to all gender nonconforming respondents who also had coexisting marginalized identities, their gender identity was the most salient to them in regard to their lack of social support both before and during their college experience.

\subsection{Coping: Respondents' Perception of the Risk of "Living Authentically"}

Many respondents viewed the university as a fresh start where they could live authentically, and the resilience of making it through high school without social support was seen as an empowering force for their decision to be open about their gender and sexual identities during all of their college experiences. Respondents expressed increased resiliency due to their lack of support. Eli stated,

"I didn't have anyone, but I was also very very very hiding my entire self in the closet. So I was just biding my time until I was 18 and I could tell my family. If they kicked me out, I would get to leave ... I sorta was applying [to college] on like a hope and a prayer that I'd get in. But, um, I didn't know how I was going to pay for it. Or how I was going to get here, or anything like that. I just knew I needed to like, get out of where I was. And this was far enough away. With instate tuition ... There was also that constant fear when I was doing it that I would be like, a token minority. My friends call me the diversity uniform because I fit so many boxes. But I couldn't talk to anyone about it, cause I was, you know, hiding all of it from everyone [in their hometown]."

Many respondents discussed college as a space where they could undergo the process of self-discovery, often perceiving university campuses to be more liberal than the rural hometowns many respondents were from. They recalled a desire to live authentically while at college, and not hide their identity any longer.

This authentic embodiment, as expressed by respondents, came through their resilience in the face of systematic discrimination and social isolation within the system of education. Many respondents expressed being unable to embody their gender identity or sexualit(ies) in their lives before entering college. However, once in the university setting, respondents wanted to live authentically, owning their identity without shame. Eli's decision to come out was also related to the timing of gaining social support on the university campus through diversity centers and peer mentoring other queer students. Eli stated,

"I wasn't ready for any of my coming out process but when I got here [the university], you know, I didn't want to lie about who I was anymore. I wanted to be me. It was something that I'd never been able to be."

Eli expressed their desire to live authentically and unfiltered in a way that was inaccessible to them in their hometown due to homophobia, discrimination, and fear of retribution-even dealing with the threat of getting kicked out of their childhood home. For many queer students, coming out before they are able to be financially independent poses a threat to their housing situation and familial relationships; therefore, in order to protect their safety, most queer students are forced to stay in the metaphorical closet until they are in a space that seems safe, accepting, or at minimum nonviolent toward queer folks. Respondents who came from small or rural towns often they held a belief that university campuses were a safe space for queer folks, as they saw the university as vastly more liberal, accepting, or progressive than their more rural and conservative hometowns, all of which are located in the southern United States. A desire to live authentically, experience new social worlds, and find a queer community were driving factors for many queer students' decisions to attend college. 


\subsection{Institutional Support}

The need for institutional support was epitomized by Amy, a working class lesbian, who, when discussing her coming out process and the isolation she faced, explained,

"I had a lot of the opposite of support in my school system actually. I had a lot of different mental health issues that were going on; on top of that I was bullied, cause even though I wasn't out, people kind of assumed ... I was bullied a lot in high school ... And I actually had to transfer high schools, so my last year of high school, um my senior year, I went to [local arts college] they have a high school program, and that- I was very lucky to go there, and that, my mother definitely helped me go there and get out of the um, bad space that I was in for the first three years of high school ... I loved it, it was definitely a safe haven, where before [at previous high school] I wasn't accepted. I was threatened emotionally, physically, and then I got to basically gay heaven. It was great ... I definitely have those roles [mentors] with figures in the GLBT center so I found out about them before I came here. I wanted to make sure I went to a school that had a GLBT center, and I realized a lot of schools only have one diversity office [for all minority identities]."

After facing bullying for the first three years of high school, Amy was unable to stay at her school. The school that Amy transitioned to for her senior year of high school was an arts-focused university that offered a dual enrollment program, which she felt caused there to be a larger queer representation and acceptance. Amy had to move high schools in order to feel safe, and she wanted to avoid entering the same kind of dangerous and invalidating environment as her initial high school. Therefore, she did thorough research about the universities she applied to attend, and sought institutional support through the diversity centers.

All respondents presented their lives as lacking the same levels of support that their heteronormative peers have, often leading to a feeling of isolation or fear. Once inside the institution of higher education, queer identified students often expressed surprise at the lack of support and aid, aside from their queer peers. Informal support was identified in the diversity centers on campus, but students also admitted fear of initially entering into those spaces and outing themselves on campus. The respondents found that at the LGBT center on campus they felt more comfortable and could live in an "unfiltered" way. Carmen, an upper-middle class bisexual woman, stated, "I use it [the LGBT center] mainly as a space to socialize, but it is nice, you know, to go in there and know that everyone there is like you or at least like accepting of bisexuality." Queer students expressed feeling safer both physically and socially in the LGBT center, and when respondents felt safe or supported they recall being able to more fully embody their queer identity and live authentically. Dylan, a chronically ill queer trans man, stated,

"I was the first person to come out as any flavor of queer ... I started going to the GLBT center a lot. And that's where I kinda like found my space on campus. I hung out at the center a lot to just talk to people, and that's where I met a lot of people I hung out with freshmen year. Yeah, so those are the two groups I kinda hang out with ... In the marching band-I have like one friend who is queer. He didn't even do color guard he just like found his way into our friend group. But he and I are, it's enough to like where they all are allies but are really chill about it- like they don't make it about them. It was mostly queer people, because um, I don't know, I like to hang out with people like me, you know?"

Many respondents found that only in the center were they not viewed as a token minority. When discussing being the only queer member of a club for her major Amy, a lesbian from a low-income background, said she was "definitely the queerest one of them." Amy was the only respondent who expressed identification with an organization or club that was not connected to the diversity and inclusion offices on campus. 
In addition to the LGBT center, allies were mentioned as bringing forward a feeling of safety and identity validation on the university campus. The respondents' university offers an ally training that covers LGBT issues more generally and then advises university faculty, staff, and students to promote LGBT awareness and support across the campus. Carmen said, "I really like when professors have gone through the center's ally training ... they'll put the little card [which indicates they have completed the training] up on their door so that people will know." Anita, a low-income, bisexual, black woman, felt that the optional ally training was not enough, and she was not alone: Mars and Eli also expressed dissatisfaction with the university's attempt to validate and recognize queer identities. In an attempt to air her frustration at the lack of diversity initiatives for queer students Anita claimed that the university uses queer students to meet quotas but does not attempt to provide diversity awareness across the university's campus.

An overall sense of frustration and exploitation with the lack of support on the university campus was felt by most respondents, one of which stated, “To them we don't exist ... If they cared more about marginalized populations than they do about, I don't know, the athletes or engineers ... But the university thinks of us as an afterthought." Respondents mentioned a desire to have aid from someone on campus with more power than themselves, but this support is often unavailable to nonheteronormative-passing queer students. Many stated that having policies that aided the recognition of queer students and their unique needs would be a helpful form of support, although they did also seek aid from a queer or ally mentor on a personal one-on-one level as well.

\subsection{Prosocial Behavior: Peer Mentorship}

This study found that eight out of ten respondents who did not have a mentor themselves reported being an informal peer mentor for other students in the queer community. Mentoring relationships with allies, according to respondents, were helpful, but not very close; these relationships were also rare. Many more acts of prosocial behavior were mentioned, such as students forming mentoring relationships with other queer students, due to the student's involvement with a campus diversity center, as the university-based LGBT center was noted as the hub of connection for all but one respondent.

While recounting their own lack of social support respondents steered the interview towards a discussion of the ways through which they attempt to prevent other queer students from facing the situations they have. Most respondents indicated that they volunteer, mentor, or support marginalized communities because they want to help or give back in ways they did not have access to. Students positively accounted their experiences of prosocial behavior motivated by their deficit in support; these accounts revolved around their ability to work with marginalized populations such as disability services, the multicultural center, or the LGBT center on campus. One student stated,

"Being here allowed me to work with some of the underexposed communities that I love... I actually, joined a club called The Allies for Students with Disabilities. I stepped into the mentor role for a lot of people. Um, and I started like volunteering at the GLBT center ... I love the folks at the center; they're all wonderful."

However, the center the student spoke about is also undergoing issues with staff turnover, lack of support on the systemic level, and loss of funding. Other respondents viewed the center as a way the university could avoid dealing with queer issues on campus. As they stated and other respondents also conveyed, "Well we have the campus GLBT center, which I think the university regards as like a band aid. Like this is our fix; give them a center, they're good. But it isn't perfect." The center, which almost all of the respondents access frequently, has a variety of clubs and organizations supporting various marginalized communities; these spaces were often spoken up as a positive light in a community where queer students often feel very disrespected, ostracized, or harassed. Most importantly, all but one respondent acknowledged the LGBT center or clubs supervised by the center as a source of affirmation on the college campus; these respondents also hold leadership roles 
within the organizations, volunteered, or expressed other forms of prosocial behavior toward the queer community.

The sentiment of being a spokesperson or representative for the queer community was pervasive throughout all of the interviews with respondents. Rickey, a Latinx Brazilian first-generation US citizen and gay man, mentioned how crucial his work at the center was for his self-development and how it satisfied his desire to help others develop their identities as well. Rickey is serving on the search committee for a new director of the center, and he has a leadership role in an organization sponsored through the center, expressing multiple avenues through which he conducted prosocial behavior to aid the queer community. Similarly serving in a leadership role through a club associated with the diversity centers on campus and reflecting on her future career in teaching Ezera stated,

"It's different being in a leadership role. I'm now trying to figure out what was missing from the year before that I would like to implement this year. I want to make sure it's something that not only I can enjoy but other people can enjoy as well ... When I do become a teacher I want to provide a space that I know I didn't have in high school and create like a GSA [gender sexuality alliance] or something."

Students also stated that their identities have a tendency to be affirmed in the diversity center in ways that they are not in most other areas of campus, positing the importance of institutional support. Various respondents stated that they have been misgendered-a microaggression that can have detrimental consequences to trans or gender nonconforming folks-due to a lack of pronoun representation in classes, other clubs, or university activities; this is just one of countless examples of identity work respondents must conduct outside the safe space of diversity offices.

For some respondents their decision to aid other members of the queer community began even before college in correspondence to the development of resiliency. When asked about his high school experiences Rickey spoke to his coming out process and starting an organization that would provide a safe space at his high school for other queer students,

"I was like 'I'm gay' and I'm just stepping out of the closet so I should start a GSA, then I was like 'oh I like this.' I like providing this presence and this space for students ... By the time I was a junior that [his goal] shifted to helping people find their beginnings since I came in and I got involved, like not everyone does that, so how can I help students make the most of it, their time here. It shifted towards like trying to give back in a way that I would've benefited I guess."

Anita reported benefiting from prosocial behavior such as peer mentorship, claiming that all of her support on the university campus was found in her primarily queer friend group. Other members of the university campus looked down on queer students and other marginalized identities, according to Anita, who emphasized the salience of her coexisting marginalized identities as a Black bisexual woman,

"You're assumed not to know things just because of your ethnicity, your face, your gender, you're just assumed to have this certain level of understanding and that's it. For most of us it's frustrating you know; you feel like you always gotta work ten times as hard to be taken as serious."

As a black woman Anita said that people often invoke the strong black woman stereotype, leaving her feeling "like I have on that invisibility cloak." She feels that as a bisexual black woman people often assume she is straight due to her ability to 'pass.' Anita felt that without the prosocial behavior from her queer peers and through mentorship she would not be able to bare the struggles of having coexisting marginalized identities at the university. 


\section{Discussion}

\subsection{Coping with the Mentor Deficit: Resiliency and Authenticity}

Queer identified students would be expected to have some sort of mentoring relationships, albeit less than those of their heteronormative peers. Seventy-four percent of youth were found to have mentoring relationships in Erickson et al. (2009) study utilizing an expansive quantitative data source. However, within this project only twenty percent of respondents $(n=10)$ were able to recall a mentor before entering college. The majority of the queer students interviewed in this sample were not able to identify a mentor in their life before entering college. Concurrent with the literature on social class, students who perceived their socioeconomic class to be upper middle, or had parents who obtained a graduate degree, were the only respondents to have informal mentoring relationships during their high school experiences as well as the opportunity to be open and 'out' about their queer identit(ies) since they have identified as queer. In this study higher income queer students identified informal mentorships while low-income queer students were not able to identify any mentorships; these demographic differences in class and mentoring relationships is in support with much of the sociological literature surrounding socioeconomic class and mentoring relationships (Erickson et al. 2009).

This finding - that only twenty percent of the respondents $(n=10)$ were able to recall a mentor before entering college-speaks to the deficit in mentoring relationships for queer identified students. However, once at the university for some time respondents did emphasize that they were able to find support through different resources, such as cultural and diversity centers or clubs for marginalized groups on campus. Eventually many of the respondents who did not have a mentor themselves became an informal peer mentor for other students in the queer community. Although the feeling of isolation during the transition from high school to college was expressed by most of the students interviewed, many students perceived that they overcame this deficiency in support and aid through their self-reliance, independence, and resiliency. Recalling their coming out process, interviewees frequently identified their ability to be out as a way to express their true selves and live authentically. Additionally, after their coming out process respondents tended to discuss their resiliency, even acknowledging the fact that the levels of social support or mentorship that their heteronormative peers were able to access was far superior to their own level of access. The authenticity described by participants was often noted as the beginning of their resiliency through both the social and economic issues they faced due to coming out as a queer individual.

Once they entered the university setting, respondents expressed recognizing that heteronormative students often had representation or support from the university in ways that they did not. Contradictory to the literature on resilience and life course development, these students perceived their resiliency stemmed from their exclusion due to their queer identity. The identity-based risk of being queer, similarly to a resource-based risk of being from a low-income background, limits the ability of students to access resources, such as mentoring relationships. Whereas, previous research has supported the claim that having social support, such as family and community, aids the individual's sense of resiliency (Ungar 2004; Werner et al. 1971), the students interviewed perceived their resiliency developed due to their social isolation and exclusion due to their identity-based risk of being openly queer. Disadvantaged students, then, often utilize these resources of mentorship in order to "catch up" to their advantaged peers. For the queer identified students in this project, their identity as a member of the queer community, and the 'risk' one must live with, forced them to develop resiliency even without high levels of social support (Ungar 2004; Werner et al. 1971).

In order to challenge the heteronormative standards of higher education many queer students proudly own their marginalized identity, viewing it as a form of self-discovery, and express their coming out process in higher education as an ownership and embodiment of their true selves. To overcome their deficiency in support many respondents felt that they did not need mentoring relationships because they felt that they were able to navigate issues on their own, placing agency on themselves. 
Resiliency as a result of exclusion based on identity - which later served to inspire prosocial behavior through mentoring other queer students—-was perceived by ninety percent of the students interviewed. Socioeconomic status has often been framed as an at-risk status leading typically to lower levels of resiliency, dependent upon support from community, friends, and lovers, perhaps family and relatives, chosen or not (Ungar 2004). Within this study it became apparent that being a member of the queer community posed an identity-based risk for social support-similarly to socioeconomic status-but the students also felt that their queer identity caused an increase in resiliency. This tendency for self-reliance and internal motivation are common throughout the queer community, as most institutions within society have not adapted to meet the needs of queer individuals; therefore, being confident in one's independence and resiliency may serve as a coping mechanism for many students who do not have the ability to get advice, support, and resources from a mentor. Respondents identified that their marginalized identity increased resiliency even though it also increased their risk of not having access to mentoring relationships.

Queer students possess an identity-based risk, which according to the current understandings on resiliency (Ungar 2004; Werner et al. 1971), should mean that such students would have a lower sense of resiliency than their peers; however, respondents in this project expressed that their identity as a member of the queer community aided in their sense of resiliency, even while living with other resource-based risks of economic insecurity and homophobic discrimination. Many of the respondents identified the resilience of making it through high school-where respondents faced discrimination, violence, and harassment-as an catalytic force for their decision to be open about their gender and sexual identities during their college experience. Therefore, this research posits that the salience of identities with 'risk' can be more influential to one's sense of resiliency than simply examining risk based on resource.

\subsection{Institutional Support}

Students with marginalized identities are less likely to have the social and cultural capital necessary to navigate the institution of higher education, and outside of the institution of education people of color, women, and low-income folks are less likely to have access to the social networks that heteronormative, white, men can (Damaske 2009). Along with mentoring, support of the educational institution is also important for students' success (Schueths and Carranza 2012). Institutional supports often aid low-income students, and other marginalized identities, the social capital necessary to navigate education (Stanton-Salazar 2011).

Queer individuals are often less visible within society, as sexuality and gender are not always aesthetically discernible, exemplifying the importance for inclusive/safe spaces (Hayfield et al. 2013). Efforts to create safe and inclusive spaces for queer individuals have bloomed dramatically in higher education; these queer student centers are often noted as the most supportive space on university campuses for queer students, where students can receive support and aid in their plans for the future (Ecker et al. 2015). Efforts at creating more diverse communities within education, where minority students feel safe and welcome, have become common but, these attempts are often merely a perpetuation of controlling forces perpetuated against structurally disadvantaged groups throughout society (Smith and Mayorga-Gallo 2017). Diversity centers on campus provide representation for minority students, while power is retained in the hands of the dominant forces within society, even within diverse spaces (Berrey 2015; Smith and Mayorga-Gallo 2017).

Respondents perceived that they have less support than their heteronormative peers, and many felt inauthentic, discriminated against, or uncomfortable in their hometowns or lives before coming out and claiming their queer identity. At college queer identified students often were surprised at the lack of social support, aside from their queer peers. Informal support was mentioned in the diversity centers on campus; these safe spaces serve to aid in the respondents' construction of their own identity. Through interactions with other queer identified students, respondents were able to construct their 
own identity and community through their interactions with other queer students. At the LGBT center on campus students expressed that they felt more comfortable and could live in an unfiltered way.

The system of education, as all social institutions, is founded on assumptions of heteronormativity, making it difficult for queer students to feel comfortable and authentic within those institutions. In order to have their identity as a member of the queer community validated, and in order to see representation of the LGBT+ community on the university's campus, many students spend time at the university's diversity center for queer students. The queer students within this project expressed feeling safer both physically and socially in the LGBT center. The authentic way that respondents felt they could express themselves in the LGBT center serves as a form of identity validation. Feeling unsupported, and even at times unsafe, on campus queer students are able to utilize the center for gender and sexuality minorities in order to be with other queer students, both building community and validating their identity as a queer individual since this validation is not provided other places on the university campus.

Many respondents felt that they could not truly embody their queer identity at the university; the heteronormative structures and assumptions that underlie society are also present within the institution of education. When respondents felt safe or supported they recalled being able to more fully embody their queer identity and live authentically. Feeling overlooked, respondents perceived the university to avoid taking action to support the needs of queer students, while feeling like an "afterthought" by the university. The support so widely accessible to other students is often unavailable to nonheteronormative-passing queer students. The anxiety and fear experienced by queer students was accredited to not only prejudiced students on the university's campus, but also to the lack of support felt on a structural-level from the university itself, emphasizing the importance of location and the power of social institutions on individual perceptions of safety and acceptance. Many participants stated that having policies that aided the recognition of queer students and their unique needs would be a helpful form of support, if enacted by the university.

\subsection{Prosocial Behavior}

This study found that respondents often performed prosocial behavior because of negative experiences: a deficit of mentorship in their own lives. Therefore, this project identifies the process through which exclusion and isolation due to queer identity serve to motivate individuals to enact prosocial behavior through mentoring others. Unlike the frequently invoked, and well-supported, notion that the origins of prosocial behavior are tied to positive experiences (Batson 1991; Dodge et al. 1990), this study found that respondents often performed prosocial behavior because of negative experiences: a deficit of mentorship in their own lives.

The importance of other social actors is indubitable to one's likelihood for prosocial behavior. Positive socialization strongly correlates to higher rates of altruism and prosocial behavior (Staub 2004; Staub 2005). Furthermore, having social support through parents, peers, and role models have been shown to predict prosocial behavior (Piliavin and Callero 1991). However, this study identifies the process through which exclusion and isolation due to queer identity serve to motivate individuals to enact prosocial behavior through mentoring others. Other scholars have noted how suffering or adverse life experiences can also enhance individuals' motivation to help others, most notably out-groups within society (Staub 2003; Vollhardt 2009), but the volume of this literature pales in comparison to the aforementioned literature, which credits prosocial behavior as an effect of positive life experiences. This study contributes to the literature on adverse life experiences as motivation for prosocial behavior for marginalized groups within society, finding that almost all respondents were either mentors, volunteers, or aided the queer and other marginalized identity-based communities.

Most students interviewed were not able to identify a mentor in their lives before entering college, and those that were identified after entering college tended to be allies, not identifying as queer themselves, but were knowledgeable with queer issues. Although previous literature has been able to correlate socioeconomic status to mentoring relationships and their benefits (DuBois and Silverthorn 2005; Erickson et al. 2009), the literature does not expose the ways through which exclusion 
limits the mentoring relationships within an identity-based community, such as the queer community. Although few mentoring relationships were reported within the data, none of the mentors openly identified as queer. Most mentoring relationships were due to the student's involvement with a campus diversity center, as the university-based LGBT center was noted as the hub of connection for all but one respondent. At the center, students felt that they could live more authentically and connect with other students, eventually forming peer mentoring relationships.

Even though they did not experience a mentoring relationship themselves as a mentee, once in the university, many students identified a way in which they served as a mentor to others, most of which occurred through safe spaces on campus within offices under the program of diversity and inclusion. The intention to mentor others due to their own lack of mentorship was not mentioned by respondents directly; however, while recounting their own lack of social support respondents steered the interview towards a discussion of the ways through which they attempt to prevent other queer students from facing the situations they have. All respondents indicated that they volunteer, mentor, or support marginalized communities because they want to help or give back in ways they did not have access to, supporting the literature on adverse life experiences as motivating prosocial behavior (Staub 2003; Vollhardt 2009). Respondents spoke to their ability to work with marginalized populations such as disability services, the multicultural center, or the LGBT center on campus; students sought to connect with other marginalized communities in ways that benefited themselves, but also in ways that allowed for prosocial behavior.

Almost every respondent acknowledged the LGBT center or clubs supervised by the center as a source of affirmation on the college campus. Many students also hold leadership roles within the organizations, volunteered, or expressed other forms of prosocial behavior toward the queer community. It is important to note the location of prosocial behavior within this study, in spaces respondents regarded as safe on the university campus, around other students with similarly marginalized identities. Students' identities are affirmed in the diversity center in ways that they are not in most other areas of campus, further positing the importance of location and space. Respondents also account benefiting from prosocial behavior such as peer mentorship often within a primarily queer friend group within these diversity centers or safe spaces on the university campus. Students expressed that without the prosocial behavior from queer peers, through mentorship, they would have a much more difficult time at the university especially for respondents with coexisting marginalized identities.

\section{Materials and Methods}

\subsection{Recruitment and Data Collection}

For this project I collected 10 in-depth and semistructured interviews with students who identify as queer at a public university in the Southeast United States. The initial participant was contacted at the university's center for LGBT+ students. From there, collecting the sample came to fruition through respondent driven sampling.

Participants had to be undergraduate students, identify as queer, and be 18 years of age or older. Interviews were conducted from September 2018 to November 2018, and generally lasted between 45 minutes and 1 hour. Participants were asked about their experiences both before and after entering the university, social support, mentorship, and their identity in the queer community in an anticategorical manner in line with queer theoretical approaches. All data were anonymized and participants were given a pseudonym.

\subsection{Sample}

The sample for this project consisted of ten undergraduate students: 4 cis-gender women (pronouns: she/her), 3 cis-gender men (pronouns: he/him), and 3 folks whose gender is not bounded by the gender/sex binary: gender fluid (pronouns: they/them), agender (pronouns: they/them), transgender man (pronouns: he/him). As self-identified, the participants' age ranged from 19 to 
22 years old, and their sexualities included gay, lesbian, bisexual, pansexual, demisexual, and queer. Sixty percent of the sample was white, with 10\% being African American, and 20\% identifying as multiracial. Using their parents' highest level of education and their perceived socioeconomic class participants were coded as poor, working, lower-middle, middle, or upper-middle class.

\subsection{Analysis}

The ten interviews all took place in a conference room on the university's campus, and the interview was recorded with a digital voice recorder. Shortly after the interview, the recording was transcribed. Open and focused coding took place through a grounded theory approach to explore patterns within the data through analysis of the respondents' lived experiences as recounted in the interview transcripts (Charmaz 2014). Utilizing the inductive process posited by grounded theory there was a reflexive process between data collection and analysis, with each influencing the other. In order to expand on the codes found within the data exploration into themes and patterns took place through memo writing, which allowed me to identify patterns in queer students' mentoring relationships, social support, and prosocial behavior. This project applies the lens of queer theory, a critical framework where both data collection and analysis are done in an anticategorical manner, focusing on the lived experiences of the respondents and their perceptions of the social world (Brim and Ghaziani 2016; Browne and Nash 2016; McDonald 2015; 2017; Valocchi 2005). This project explores how the process of mentorship is influenced by being a member of the queer community. Please see Table 1 as below.

Table 1. Sample demographics.

\begin{tabular}{|c|c|c|c|c|c|c|}
\hline $\begin{array}{l}\text { Pseudonym } \\
\text { \& Pronouns }\end{array}$ & Age & Gender & Sexuality & Race/Ethnicity & $\begin{array}{l}\text { Parents' Highest } \\
\text { Level of Education }\end{array}$ & $\begin{array}{l}\text { Socioeconomic } \\
\text { Class }\end{array}$ \\
\hline $\begin{array}{c}\text { Eli } \\
\text { (they/them) }\end{array}$ & 21 & Gender fluid & $\begin{array}{l}\text { Pansexual, } \\
\text { demisexual }\end{array}$ & $\begin{array}{l}\text { White, Native } \\
\text { American }\end{array}$ & GED & Poor/Working \\
\hline $\begin{array}{c}\text { Ezera } \\
\text { (she/her) }\end{array}$ & 22 & Cis-female & Bisexual & Hispanic, White & Community College & Lower Middle \\
\hline $\begin{array}{l}\text { Dylan } \\
\text { (he/him) }\end{array}$ & 22 & Male & Queer & White & Graduate School & Upper Middle \\
\hline $\begin{array}{l}\text { Rickey } \\
\text { (he/him) }\end{array}$ & 22 & Man & Gay & Latinx & High School & Working \\
\hline $\begin{array}{c}\text { Mars } \\
\text { (they/them) }\end{array}$ & 21 & Agender & Pansexual & White & Graduate School & Middle \\
\hline $\begin{array}{l}\text { Carmen } \\
\text { (she/her) }\end{array}$ & 20 & Cis-female & Bisexual & White & Graduate School & Upper Middle \\
\hline $\begin{array}{l}\text { Cooper } \\
\text { (he/him) }\end{array}$ & 20 & Cis-male & Gay & White & College & Middle \\
\hline $\begin{array}{c}\text { Oakley } \\
\text { (he/him) }\end{array}$ & 20 & Male & Gay & White & High School & Working \\
\hline $\begin{array}{c}\text { Anita } \\
\text { (she/her) }\end{array}$ & 21 & Cis-female & Bisexual & $\begin{array}{l}\text { African } \\
\text { American }\end{array}$ & High School & Working \\
\hline $\begin{array}{c}\text { Amy } \\
\text { (she/her) }\end{array}$ & 19 & Cis-woman & Lesbian & White & College & Working \\
\hline
\end{tabular}

\section{Conclusions}

\subsection{Implications}

Sociological research has examined processes surrounding social support and mentoring, in regard to minority populations within education. The literature has shown that mentoring can help disadvantaged students access social and cultural capital that aids their academic achievement. This project specifically examined queer students' experiences with mentoring relationships in regard to education. Queer identified students within the sample recalled past experiences of social exclusion, 
as well as ways through which they coped through resiliency. Ultimately, queer students gave back to their community through the prosocial behavior of mentoring other queer students on the college campus. This project found that being openly queer posed an identity-based risk for students' ability to access mentoring relationships; in turn this risk increased their perception of resiliency and prosocial behavior.

\subsection{Limitations and Future Research}

The sample $(\mathrm{n}=10)$ was collected through a respondent driven sampling method, which began by contacting students at the university's center for LGBT+ students. Due to the location of initial recruitment the sample does contain many students who are well connected to the LGBT+ center on the university's campus. This limitation may influence the relationship between risks students possess and the process of developing resiliency. However, the sampling technique employed also allowed a more in depth look at the institutional supports at the university in a way that other methods of participant recruitment may not have allowed.

Funding: This research received no external funding.

Conflicts of Interest: The author declares no conflict of interest.

\section{References}

Allen, Joseph P., and Deborah Land. 1999. Attachment in adolescence. In Handbook of Attachment Theory and Research. New York: Guilford Press, pp. 319-35.

Anderson, Eugene M., and Anne Lucasse Shannon. 1988. Toward a conceptualization of mentoring. Journal of Teacher Education 39: 38-42. [CrossRef]

Batson, C. Daniel. 1991. The Altruism Question: Toward a Social-Psychological Answer. Hillsdale: Lawerence Erlbaum.

Beam, Margaret R., Chuansheng Chen, and Ellen Greenberger. 2002. The Nature of Adolescents' Relationships with Their 'Very Important' Nonparental Adults. American Journal of Community Psychology 30: 305-25. [CrossRef] [PubMed]

Berrey, Ellen. 2015. The Enigma of Diversity: The Language of Race and the Limits of Racial Justice. Chicago: The University of Chicago Press.

Bird, Jason D. P., Lisa Kuhns, and Robert Garofalo. 2011. The Impact of Role Models on Health Outcomes for Lesbian, Gay, Bisexual, and Transgender Youth. Journal of Adolescent Health. 50: 353-57. [CrossRef] [PubMed]

Blonshine, Rebekah. 2014. Impact on Mentoring on Former Pre-College Program Participants: Gaining While Giving Back. Los Angeles: University of Southern California.

Bourdieu, Pierre. 1994. Social Space and Symbolic Space. Calhoun, Contemporary Social Theory, 2nd ed. Malden: Blackwell Publishing, pp. 267-76.

Brim, Matt, and Amin Ghaziani. 2016. Introduction: Queer Methods. Women's Studies Quarterly 44: 14-27. [CrossRef]

Browne, Kath, and Catherine J. Nash. 2016. Queer Methods and Methodologies: Intersecting Queer Theories and Social Science Research. New York: Routledge.

Chang, Esther S., Ellen Greenberger, Chuansheng Chen, Jutta Heckhausen, and Susan P. Farruggia. 2010. Nonparental adults as social resources in the transition to adulthood. Journal of Research on Adolescence 20: 1065-82. [CrossRef]

Charmaz, Kathy. 2014. Constructing Grounded Theory, 2nd ed. Thousand Oaks: Sage Publications Ltd.

Chase, Sarah. 2010. First-Generation Faculty: A Phenomenological Exploration of Their Motivations for Mentoring First-Generation Students. Greeley: University of Northern Colorado, College of Education and Behavioral Sciences, School of Educational Research, Leadership, and Technology, Higher Education and Student Affairs Leadership.

Chica, Christina Marie. 2019. Queer Integrative Marginalization: LGBTQ Integration Strategies at an Elite University. Socius: Sociological Research for a Dynamic World 5: 1-13. [CrossRef]

Collins, Patricia Hill. 1991. Controlling Images and Black Women's Oppression. In Black Feminist Thought: Knowledge, Consciousness, and the Politics of Empowerment. New York: Routledge. 
Collins, Patricia Hill. 2005. Black Sexual Politics: African Americans, Gender, and the New Racism. New York: Routledge.

Damaske, Sarah. 2009. Brown Suits Need Not Apply: The Intersection of Race, Gender, and Class in Institutional Network Building. Sociological Forum 24: 402-24. [CrossRef]

Dodge, K., J. Bates, and G. Pettit. 1990. Mechanisms in the Cycle of Violence. Science 250: 1678-83. [CrossRef]

DuBois, David L., and Naida Silverthorn. 2005. Characteristics of Natural Mentoring Relationships and Adolescent Adjustment: Evidence from a National Study. The Journal of Primary Prevention 26: 69-92. [CrossRef]

Duntley-Matos, Roxanna. 2014. Transformative Complicity and Cultural Humility: De- and Re-Constructing Higher Education Mentorship for Under-represented Groups. Qualitative Sociology 37: 443-66. [CrossRef]

Ecker, John, Jennifer Rae, and Amandeep Bassi. 2015. Showing your pride: A national survey of queer student centres in Canadian colleges and universities. Higher Education 70: 881-98. [CrossRef]

Erickson, Lance D., Steve McDonald, and Glen H. Elder Jr. 2009. Informal Mentors and Education: Complementary or Compensatory Resources? Sociology of Education 82: 344-67. [CrossRef] [PubMed]

Farruggia, Susan P., Pat Bullen, and Joy Davidson. 2013. Important Nonparental Adults as an Academic Resource for Youth. The Journal of Early Adolescence 33: 498-522. [CrossRef]

Fruiht, Veronica M. 2015. Supportive Others in the Lives of College Students and Their Relevance to Hope. Journal of College Student Retention: Research, Theory \& Practice 17: 64-87.

Fruiht, Veronica M., and Laura Wray-Lake. 2013. The role of mentor type and timing in predicting educational attainment. Journal of Youth and Adolescence 42: 1459-72. [CrossRef] [PubMed]

Gaddis, S. Michael. 2012. What's in a Relationship? An Examination of Social Capital, Race and Class in Mentoring Relationships. Social Forces 90: 1237-69. [CrossRef]

Hayfield, Nikki, Victoria Clarke, Emma Holliwell, and Helen Malson. 2013. Visible lesbians and invisible bisexuals: Appearance and visual identities among bisexual women. Women's Studies International Forum 40: 172-82. [CrossRef]

Hinsdale, Mary. 2011. Responsive Mentor, Transformative Mentorship. Salt Lake City: University of Utah, Department of Education, Culture, and Society.

Hurd, Noelle M., and Robert M. Sellers. 2013. Black Adolescents' Relationships with Natural Mentors: Associations with Academic Engagement via Social and Emotional Development. Cultural Diversity and Ethnic Minority Psychology 19: 76-85. [CrossRef]

Jack, Anthony Abraham. 2016. (No) Harm in Asking: Class, Acquired Cultural Capital, and Academic Engagement at an Elite University. Sociology of Education 89: 1-19. [CrossRef]

Katz, Joseph, and Rodney T. Hartnett. 1976. Scholars in the Making. Cambridge: Ballinger.

Lareau, Annette. 1987. Social Class Differences in Family-School Relationships: The Importance of Cultural Capital. Sociology of Education 60: 73-85. [CrossRef]

Lareau, Annette. 2003. Unequal Childhoods: Class, Race, and Family Life. Berkeley: University of California Press.

Lehmann, Wolfgang. 2017. Habitus Transformation and Hidden Injuries: Successful Working-class University Students. Sociology of Education 87: 1-15. [CrossRef]

Liao, C. Lynn, and Bernadette Sánchez. 2016. Mentoring Relationship Quality Profiles and Their Association with Urban, Low-Income Youth's Academic Outcomes. Youth E Society 51: 443-62.

Malacarne, Timothy. 2017. Rich Friends, Poor Friends: Inter-Socioeconomic Status Friendships in Secondary School. Socius: Sociological Research for a Dynamic World 3: 1-13. [CrossRef]

McDonald, James. 2015. Organizational Communication Meets Queer Theory: Theorizing Relations of 'Difference' Differently. Communication Theory 25: 310-29. [CrossRef]

McDonald, James. 2017. Queering methodologies and organizational research: Disrupting, critiquing, and exploring. Qualitative Research in Organizations and Management 12: 130-48. [CrossRef]

Moore, Mignon. 2015. LGBT Populations in Studies of Urban Neighborhoods: Making the Invisible Visible. City and Community 14: 245-48. [CrossRef]

Morris, Aldon. 2017. W.E.B. DuBois at the Center: from science, to Civil Rights Movement, to Black Lives Matter. The British Journal of Sociology 68: 3-16. [CrossRef] [PubMed]

Mulcahy, Molly, Sarah Dalton, Jered Kolbert, and Laura Crothers. 2016. Informal mentoring for lesbian, gay, bisexual, and transgender students. The Journal of Educational Research 109: 405-12. [CrossRef]

Mullen, Ann L. 2010. Degrees of Inequality: Culture, Class, and Gender in American Higher Education. Baltimore: Johns Hopkins University Press. 
Nicol, Hannah. 2011. College Student Leadership within the LGBT Community. International Journal of Arts and Sciences 4: 15-25.

Noy, Shiri, and Rashawn Ray. 2012. Graduate Students' Perceptions of Their Advisors: Is There Systematic Disadvantage in Mentorship? The Journal of Higher Education 83: 876-914. [CrossRef]

Ortiz-Walters, Rowena, and Lucy L. Gilson. 2005. Mentoring in academia: An examination of the experiences of proteges of color. Journal of Vocational Behavior 67: 459-75. [CrossRef]

Padilla, Raymond V., and Rudolfo Chávez Chávez. 1995. The Leaning Ivory Tower: Latino Professors in American Universities. Albany: State University Press.

Parcel, Toby L., and Joshua A. Hendrix. 2014. Family Transmission of Social and Cultural Capital. In The Wiley Blackwell Companion to the Sociology of Families. Hoboken: John Wiley \& Sons, Ltd.

Piliavin, Jane Allyn, and Peter L. Callero. 1991. Giving Blood: The Development of an Altruistic Identity. Baltimore: Johns Hopkins University Press.

Reskin, Barbara F. 1979. Academic Sponsorship and Scientists' Careers. Sociology of Education 52: 129-46. [CrossRef]

Rhodes, Jean E. 2002. Stand by Me: The Risks and Rewards of Mentoring Today's Youth. Cambridge: Harvard University Press.

Rhodes, Jean E. 2005. A model of youth mentoring. In Handbook of Youth Mentoring. Thousand Oaks: Sage, pp. $143-57$.

Rist, Ray. 1970. Student Social Class and Teacher Expectations: The Self Fulfilling Prophecy in Ghetto Education. Harvard Educational Review 70: 131-74. [CrossRef]

Royster, Deirdre. 2003. Race and the Invisible Hand: How White Networks Exclude Black Men from Blue-Collar Jobs. Berkeley: University of California Press.

Russell, Glenda, and Sharon Horne. 2009. Finding Equilibrium: Mentoring, Sexual Orientation, and Gender Identity. Professional Psychology: Research and Practice 40: 194-200. [CrossRef]

Santos, Silvia J., and Elena T. Reigadas. 2005. Understanding the Student-Faculty Mentoring Process: Its Effects on At Risk University Students. Journal of College Student Retention 6: 337-57. [CrossRef]

Schueths, April M., and Miguel A. Carranza. 2012. Navigating Around Educational Roadblocks: Mentoring for Pre K to 20+ Latino/a Students. Latino Studies 10: 566-86. [CrossRef]

Smith, Candis Watts, and Sarah Mayorga-Gallo. 2017. The New Diversity Principle-policy Gap: How Diversity Ideology Subverts Diversity Initiatives. Sociological Perspectives 60: 889-911. [CrossRef]

Stanton-Salazar, Ricardo D. 2011. A social capital framework for the study of institutional agents and their role in the empowerment of low-status students and youth. Youth \& Society 43: 1066-109.

Stanton-Salazar, Ricardo D., and Stephanie Urso Spina. 2003. Informal mentors and role models in the lives of urban Mexican-origin adolescents. Anthropology E Education Quarterly 34: 231-54.

Staples, Hilary. 2014. Faculty Perceptions of Mentoring First Generation/Low Income and Underrepresented College Students at Predominantly White Institutions: An Exploratory Study. Indiana: Indiana University of Pennsylvania, Department of Sociology.

Staub, Ervin. 2003. The Psychology of Good and Evil: Why Children, Adults, and Groups Help and Harm Others. Cambridge: Cambridge University Press.

Staub, Ervin. 2004. Basic Human Needs, Altruism, and Aggression. In The Social Psychology of Good and Evil. New York: Guilford, pp. 51-84.

Staub, Ervin. 2005. The Roots of Goodness: The Fulfillment of Basic Human Needs and the Development of Caring, Helping and Nonaggression, Inclusive Caring, Moral Courage, Active Bystandership, and Altruism Born of Suffering. In Moral Motivation Through the Life Span. Lincoln: University of Nebraska Press, pp. 33-72.

Strayhorn, Terrell L., and Tonya N. Saddler. 2008. Gender Differences in the Influence of Faculty-Student Mentoring Relationships on Satisfaction with College Among African Americans. Journal of African American Studies 13: 476-93. [CrossRef]

Thomas, Emanuel. 2005. The Effects of an Ethic-Based Mentoring Model on College Adjustment, Grade Point Average, and Retention Among First Year African American College Students Attending a Predominantly White Institution. East Lansing: Michigan State University, Department of Psychology.

Turner, Caroline Sotello Viernes, and Samuel L. Myers. 2000. Faculty of Color in Academe: Bittersweet Success. Boston: Allyn and Bacon.

Ungar, Michael. 2004. The Importance of Parents and Other Caregivers to the Resilience of High-risk Adolescents. Family Process 43: 23-41. [CrossRef] [PubMed] 
Valocchi, Stephen. 2005. Not Yet Queer Enough: The Lessons of Queer Theory for the Sociology of Gender and Sexuality. Gender and Society 19: 750-70. [CrossRef]

Vollhardt, Johanna Ray. 2009. Altruism Born of Suffering and Prosocial Behavior Following Adverse Life Events: A Review and Conceptualization. Social Justice Research 22: 53-97. [CrossRef]

Werner, Emmy E., Jessie M. Bierman, and Fern E. French. 1971. The Children of Kauai; a Longitudinal Study from the Prenatal Period to Age Ten. Honolulu: University of Hawaii Press. 